FedUni ResearchOnline

http://researchonline.federation.edu.au

This is an Accepted Manuscript of an article published by Taylor \& Francis in Drying Technology on 07/03/2016, available online: 


\title{
Survival, Oxidative Stability and Surface Characteristics of Spray Dried Co-Microcapsules Containing Omega-3 Fatty Acids and Probiotic Bacteria
}

\author{
Divya Eratte, Thomas. R. Gengenbach, Kim Dowling, Colin. J. Barrow \& Benu \\ Adhikari
}

To cite this article: Divya Eratte, Thomas. R. Gengenbach, Kim Dowling, Colin. J. Barrow \& Benu Adhikari (2016): Survival, Oxidative Stability and Surface Characteristics of Spray Dried CoMicrocapsules Containing Omega-3 Fatty Acids and Probiotic Bacteria, Drying Technology, DOI: 10.1080/07373937.2016.1141782

To link to this article: http://dx.doi.org/10.1080/07373937.2016.1141782

Accepted author version posted online: 07

Mar 2016.

Submit your article to this journal ¿

View related articles $\nearrow$

View Crossmark data $־$ 


\title{
Survival, Oxidative Stability and Surface Characteristics of Spray Dried Co-Microcapsules Containing Omega-3 Fatty Acids and Probiotic Bacteria
}

\author{
Divya Eratte ${ }^{1}$, Thomas. R. Gengenbach ${ }^{2}$, Kim Dowling ${ }^{1}$, Colin. J. Barrow ${ }^{3}$, Benu \\ Adhikari $^{2,4}$ \\ ${ }^{1}$ Faculty of Science and Technology, Federation University Australia, Mount Helen, VIC, \\ Australia \\ ${ }^{2}$ CSIRO Manufacturing Flagship, Clayton, VIC \\ ${ }^{3}$ Centre for Chemistry and Biotechnology, Deakin University, Geelong, VIC, Australia \\ ${ }^{4}$ School of Applied Sciences, RMIT, Melbourne, VIC, Australia \\ Corresponding author: Kim Dowling E-mail: k.dowling@federation.edu.au
}

\begin{abstract}
The objective of the study was to determine optimum inlet and outlet air temperatures of spray process for producing co-microcapsules containing omega-3 rich tuna oil and probiotic bacteria $L$. casei. These co-microcapsules were produced using whey protein isolate and gum Arabic complex coacervates as shell materials. Improved bacterial viability and oxidative stability of omega-3 oil were used as two main criteria of this study. Three sets of inlet $\left(130^{\circ} \mathrm{C}, 150^{\circ} \mathrm{C}\right.$ and $\left.170^{\circ} \mathrm{C}\right)$ and outlet $\left(55^{\circ} \mathrm{C}, 65^{\circ} \mathrm{C}\right.$ and $\left.75^{\circ} \mathrm{C}\right)$ air temperatures were used in nine combinations to produce powdered co-microcapsule. The viability of L. casei, oxidative stability of omega-3 oil, surface oil, oil microencapsulation efficiency, moisture content, surface elemental composition and morphology of the powdered samples were measured. There is no statistical difference in oxidative stability at two lower inlet air temperatures $\left(130^{\circ} \mathrm{C}\right.$ and $\left.150^{\circ} \mathrm{C}\right)$. However, there was a significant decrease in oxidative stability when higher inlet temperature $\left(170^{\circ}\right.$ C) was used. The viability of $L$. casei decreased with the increase in the inlet and outlet
\end{abstract}


air temperatures. There was no difference in the surface elemental compositions and surface morphology of powdered co-microcapsules produced under these nine inlet/outlet temperature combinations. Of the range of conditions tested the co-microcapsules produced at inlet-outlet temperature $130-65^{\circ} \mathrm{C}$ showed the highest bacterial viability and oxidative stability of omega-3 and having the moisture content of $4.93 \pm 0.05 \%(\mathrm{w} / \mathrm{w})$. This research shows that powdered co-microcapsules of probiotic bacteria and omega-3 fatty acids with high survival of the former and high stability against oxidation can be produced through spray drying.

KEYWORDS: Co-encapsulation, omega-3 fatty acids, probiotic bacteria, spray drying, surface composition and morphology

\subsection{INTRODUCTION}

The development of functional foods and nutraceuticals by incorporating bioactive ingredients, particularly omega-3 fatty acids, probiotic bacteria, and polyphenols is a significant focus of functional and nutritional food industries. ${ }^{[1,2]}$ New nutraceutical and functional food products are being designed and manufactured to fulfil the growing demand for healthier foods. ${ }^{[3,4]}$ Two of the most widely utilised bioactive ingredients used in functional foods are probiotic bacteria ${ }^{[5,} \underline{6]}$ and omega- 3 fatty acids. ${ }^{[7,} \underline{8]}$ The functional foods developed using probiotic bacteria and omega-3 oils have clinically

proven health benefits. ${ }^{[5,9]}$ Probiotic bacteria are a group of bacteria which are defined as 'live microorganisms which when administered in adequate amounts confer a health benefit to the host' $\stackrel{[10]}{ }$ Lactobacillus and Bifidobacterium are the most commonly studied 


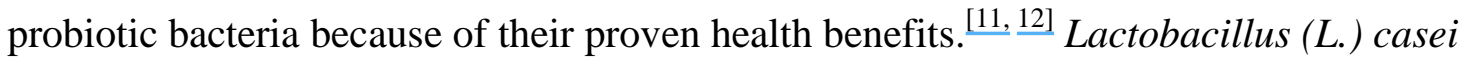
431 is used as a model probiotic (P) bacterium in this study. Omega-3 fatty acids also have clinically proven health benefits in humans. ${ }^{[13]}$ Tuna oil $(\mathrm{O})$ is used as the source of omega-3 fatty acids in this study. Whey proteins isolate (WPI) possesses very high nutritional value and good emulsifying properties. $\underline{[14, \underline{15]}}$ Gum Arabic (GA) is a complex polysaccharide and it is commonly used as thickener and emulsifier in food formulations. ${ }^{[16]}$ For these reasons, these two are used as encapsulating wall materials.

Several functional foods are manufactured using microencapsulation technology which entraps potent and unstable core within relatively inert shell to enhance shelf-life and to achieve controlled release and targeted delivery. ${ }^{[17,18]}$ Specifically, a number of microencapsulation techniques such as spray drying, fluidized bed drying, complex coacervation, extrusion, and emulsion have been used for the delivery of bioactive ingredients into food. ${ }^{[2]}$ Complex coacervation is generally regarded as a useful microencapsulation technology because it confers controlled and sustained release possibilities. ${ }^{[19]}$ Complex coacervation based encapsulation technologies are utilized to protect bioactive ingredients such as omega-3 oil ${ }^{[20]}$, ascorbic acid ${ }^{[21]}$, sweet orange oil $^{[22]}$ and probiotic bacteria. ${ }^{[23]}$ The benefits of co-encapsulation of omega-3 oil and probiotic bacteria in WPI-GA complex coacervate matrix were reported in our previous work in terms of survival and oxidative stability. $\underline{[24]}$

The liquid microcapsules produced through complex coacervation processes have to be converted into powder in order to increase shelf life, and to improve packaging, handling 
and storage properties. ${ }^{[25]}$ Spray drying is one of the most hygienic and economical technologies used for microencapsulation and producing powders in food industry. ${ }^{[26,27]}$ It is a thermally mild amongst the convective air drying methods because of its very short product residence time. ${ }^{[28]}$ The spray drying is 4-7 times less expensive than that of freeze drying. ${ }^{[29]}$ However, maintaining high viability of heat sensitive probiotic bacteria through spray drying is still a major challenge. ${ }^{[30, \underline{31]}}$ Since spray drying is much more cost effective and it can process larger volumes and operate at higher energy efficiency compared to freeze drying, many studies endeavoured to optimize spray drying process parameters and product formulations towards highest probiotic viability and minimal activity losses. ${ }^{[32,33]}$

In our previous study, we investigated the co-microencapsulation of omega-3 oil and $L$. casei produced through complex coacervation followed by freeze and spray drying. It was found that spray dried co-microcapsule powders had advantages in terms of oxidative stability of omega-3 oil; however, the freeze dried co-microcapsules had higher viability of L. casei. ${ }^{[24]}$ This work endeavours to optimise the spray drying process parameters so that co-microcapsules with higher bacterial viability as well as higher oxidative stability are produced. In addition, this study investigates the effect of inlet/outlet air tempertures on the physico-chemical and surface characteristics of spray dried co-microcapsules for the first time. These findings will benefit both the industry and the general public because of the synergistic health benefits of these powdered comicrocapsules. These co-microcapsules are robust enough to be incorporated in commonly used food items such as yoghurt and beverages. 
This study had the following objectives: (1) To determine the optimum inlet/outlet air temperature combination to produce co-microcapsules (WPI-P-O-GA) with improved viability of probiotic bacteria and better oxidative stability of omega-3 oil. (2) To evaluate the effect of spray drying inlet/outlet air tempertures on the physico-chemical properties (moisture content, surface oil, total oil, oil microencapsulation efficiency) and morphological features and surface composition of co-microcapsules.

\subsection{MATERIALS AND METHODS}

\subsection{Materials}

L. casei $431^{\circledR}$ was donated by Chr.Hansen (Horsholm, Denmark). Tuna oil (HiDHA), was obtained by courtesy of NuMega Ingredients (Melbourne, Australia) and stored at $4^{\circ} \mathrm{C}$ until used. According to data provided by the supplier, the major fatty acids in this tuna oil were as follows: DHA (docosahexaenoic acid) $29.4 \%$, palmitic acid $19.2 \%$, oleic acid 12.8\%, EPA (eicosapentaenoic acid) $6.0 \%$, stearic acid 5.3\%, myristic acid $2.4 \%$, arachidonic acid 2.0\%, decosapentaenoic acid (DPA) 1.2\%, linoleic acid 1.2\%, stearidonic acid $0.6 \%$, and linolenic acid $0.4 \%$. Whey protein isolate (WPI $895^{\mathrm{TM}}$ ) was donated by Fonterra Cooperative (Melbourne, Australia). Gum Arabic was purchased from Sigma-Aldrich (Sydney, Australia). All other chemicals were purchased from Sigma-Aldrich Australia and were of analytical grade and used without further purification.

\subsection{Preparation Of Probiotic Cell Pellets And Co-Microcapsules}


The bacterial cell pellets and co-microcapsules were prepared as described in our earlier work. ${ }^{[24]}$ Briefly, the $L$. case $i$ was cultured for $18 \mathrm{~h}$ in sterile MRS broth $(1 \%, \mathrm{w} / \mathrm{v})$ at $37^{\circ}$ C. This culture was further sub-cultured $\left(37^{\circ} \mathrm{C}, 18 \mathrm{~h}\right)$ twice in the same broth to activate bacteria and to allow them to adapt. All the inoculation works were carried out under sterile biological hoods with laminar air flow (Auramini, Laftech, Australia). Finally, $1000 \mathrm{~mL}$ of media was used for bulk culturing and cells were harvested at stationary growth phase by centrifuging at $2200 \times \mathrm{g}$ for $15 \mathrm{~min}$ at $5^{\circ} \mathrm{C}$. The supernatant was discarded and the precipitated cell mass was washed twice with sterile peptone water $(0.2 \%, \mathrm{w} / \mathrm{v})$ and these cell pellets were used for co-encapsulation process.

The co-encapsulation process was carried out as follows: Firstly, WPI solution ( $7.5 \mathrm{~g}$; $3 \%, \mathrm{w} / \mathrm{v})$ was prepared at ambient temperature and $15 \mathrm{~g}$ of tuna oil was dispersed in this solution. The mixture was stirred using a mechanical stirrer $\left(\mathrm{IKA}^{\circledR} \mathrm{RW} 20\right.$, Staufen, Germany) at $800 \mathrm{rpm}$ for $10 \mathrm{~min}$ and was further homogenized using a microfluidizer (M110L, Microfluidics, Newton, Massachusetts, USA) at $45 \mathrm{MPa}$ for 3 passes to produce an $\mathrm{O} / \mathrm{W}$ emulsion. The pure probiotic cell pellets prepared (wet mass $5 \mathrm{~g}$ ) as described above were then added into this $\mathrm{O} / \mathrm{W}$ emulsion. Then GA solution $(2.5 \mathrm{~g} ; 1 \%$, w/v) was added drop wise into this dispersion with continuous stirring at $400 \mathrm{rpm}$. The $\mathrm{pH}$ of this emulsion was then adjusted to 3.75 by adding $1 \%$ citric acid drop wise in order to induce complexation between WPI and GA. The co-microencapsulation procedure was carried out at $25^{\circ} \mathrm{C}$, and the liquid co-microcapsules were kept at $5^{\circ} \mathrm{C}$ for $48 \mathrm{~h}$ to ensure complete formation of complex coacervates. Finally, the co-microcapsules were dried to produce solid or powder co-microcapsules (WPI-P-O-GA). 


\subsection{Spray Drying Of Co-Microcapsules}

The liquid co-microcapsule samples prepared as described in Section 2.2 were spray dried (Mini spray dryer B-290, BÜCHI Labortechnik, Flawil, Switzerland) using three different inlet $\left(130^{\circ} \mathrm{C}, 150^{\circ} \mathrm{C}, 170^{\circ} \mathrm{C}\right)$ and outlet $\left(55^{\circ} \mathrm{C}, 65^{\circ} \mathrm{C}, 75^{\circ} \mathrm{C}\right)$ temperatures in nine combinations. The flow rate of the drying air was $35 \mathrm{~m}^{3} / \mathrm{h}$ at $100 \%$ fan aspiration. The pumping rate was adjusted to maintain the outlet air temperature (the feed rate varies from $1.2 \mathrm{~mL} / \mathrm{min}$ to $3.6 \mathrm{~mL} / \mathrm{min})$. The powdered co-microcapsules were collected and stored at $5^{\circ} \mathrm{C}$ for further characterization. The entire process for the production of WPIP-O-GA co-microcapsules was performed in triplicates for each inlet/outlet temperature set and the samples taken from three batches were used to determine their physicochemical characteristics.

The thermal efficiency ( $\left.\eta_{\text {thermal }}\right)$ of the spray drying operation was approximated using equation (1) ${ }^{[34]}$.

$$
\eta_{\text {thermal }}(\%)=\frac{\left(T_{\text {inlet }}-T_{\text {outlet }}\right)}{\left(T_{\text {inlet }}-T_{\text {ambient }}\right)} \times 100
$$

where $\mathrm{T}_{\text {inlet }}, \mathrm{T}_{\text {outlet, }}$ and $\mathrm{T}_{\text {ambient }}$ are inlet, outlet and ambient $\left(25^{\circ} \mathrm{C}\right)$ air temperatures, respectively.

\subsection{Enumeration Of Bacterial Viability In Powdered Co-Microcapsules}

The viability of $L$. case i in the co-microcapsules was assessed in MRS agar (CM0361, Thermo scientific, Melbourne, Australia) using spread plating technique as described in our earlier work. ${ }^{[24]}$ Briefly, $1 \mathrm{~g}$ of powder was diluted in $9 \mathrm{~mL}$ of sterile peptone water 
$(0.2 \%, \mathrm{w} / \mathrm{v})$. The bacterial cells were released from the capsules to the medium using a stomacher. The cell suspension was serially diluted and plated on MRS agar plate and incubated under anaerobic condition (Oxoid ${ }^{\mathrm{TM}}$ Anaerojar $^{\mathrm{TM}}$, Thermoscientific, Australia) at $37^{\circ} \mathrm{C}$ for $48 \mathrm{~h}$. The plating and enumeration were performed in triplicate and expressed viability as $\log \mathrm{cfu} / \mathrm{g}$.

\subsection{Assessment Of Oxidative Stability}

Accelerated oxidation tests were carried out on the powdered WPI-P-O-GA comicrocapsules using Rancimat ${ }^{\mathrm{TM}}$ test (model 743, Metrohm, Herisau, Switzerland). ${ }^{[35]}$ Two grams of dried powder was heated at $90^{\circ} \mathrm{C}$ under purified air (flow rate of $20 \mathrm{~L} / \mathrm{h}$ ). Briefly, when the encapsulated oil is oxidized, the conductivity of Milli-Q water in the collection chamber increases due to the increased solubility of volatile products (formic acid). The oxidative stability index (OSI) of the samples is graphically determined by locating tangential intersection point on experimental data. ${ }^{[20,36]}$ The induction time (at which the conductivity of sample increases sharply due to oxidation) of the test sample was recorded and used as the OSI.

\subsection{Microencapsulation Efficiency}

Microencapsulation efficiency (ME) was calculated by measuring the solvent extractable surface oil (SO) and total oil (TO) of the microcapsules. Surface oil was determined by the washing method. ${ }^{[20,32]}$ 
The total oil content in the dried microcapsules was determined by an acid digestion method using $4 \mathrm{M} \mathrm{HCl}$ according to Eratte et al. ${ }^{[20]}$ The SO, TO and ME were calculated using equations (2), (3) and (4), respectively.

$\mathrm{SO}(\%)=\frac{\mathrm{W}_{\mathrm{s}}}{\mathrm{W}_{\mathrm{m}}} \times 100$

$\mathrm{TO}(\%)=\frac{\mathrm{W}_{\mathrm{t}}}{\mathrm{W}_{\mathrm{m}}} \times 100$

$\operatorname{ME}(\%)=\frac{\mathrm{W}_{\mathrm{t}}-\mathrm{W}_{\mathrm{s}}}{\mathrm{W}_{\mathrm{t}}} \times 100$

where $\mathrm{W}_{\mathrm{t}}$ and $\mathrm{W}_{\mathrm{s}}$ are the mass $(\mathrm{g})$ values of total and surface oil of the microcapsules and $\mathrm{W}_{\mathrm{m}}$ is the mass $(\mathrm{g})$ of the microcapsules.

\subsection{Acquiring Surface Morphology Of Co-Microcapsules}

Scanning electron microscope (SEM) (JEOL JSM6300 SEM, Tokyo, Japan) was used to acquire the morphology of liquid, solid and reconstituted solid co-microcapsules. Solid samples were lightly gold sputter coated (Sputter coater, Agar Aids, England) for 45 seconds and imaged at $7 \mathrm{kV}$ and low beam current. The liquid co-microcapsules were subjected to additional treatment before gold sputter coating. Briefly, $20 \mathrm{~mL}$ of liquid comicrocapsules was fixed with $2 \%(\mathrm{w} / \mathrm{v})$ glutaraldehyde in phosphate buffer $(0.1 \mathrm{M} ; \mathrm{pH}$ 7.2) for $12 \mathrm{~h}$. The slurry containing the glutaraldehyde cross-linked co-microcapsules was dehydrated in ethanol at different concentrations $(30 \%, 40 \%, 50 \%, 60 \%, 70 \%, 80 \%$, $90 \%, 100 \%$ ), each for $30 \mathrm{~min}$. The sample was transferred to a solution containing hexamethyldisilizane (HMDS) and 100\% ethanol in the ratio of 1:2 and left undisturbed for $20 \mathrm{~min}$. HMDS is used as an alternative of critical point drying. Then, the sample was 
transferred to a fresh solution with HMDS-to-100\% ethanol ratio of 2:1 for another 20 min. Finally, the sample was transferred into $100 \%$ HMDS solution and capped loosely in the fume hood overnight. The HMDS evaporated and the resulting solid sample was gold sputter coated and imaged under SEM.

\subsection{X-Ray Photoelectron Spectroscopic (XPS) Analysis}

The surface chemical analysis was performed using an AXIS Ultra-DLD spectrometer (Kratos Analytical Ltd., UK) equipped with a monochromatic Al Ka X-ray source and a hemispherical analyser (fixed analyser transmission mode). Elemental compositions were determined from low-resolution survey spectra. High resolution C1s spectra were acquired to obtain detailed information about chemical map on the surface of the comicrocapsules.

\subsection{Moisture Content}

The moisture content of powdered co-microcapsules was determined by drying the sample in a hot air oven at $105^{\circ} \mathrm{C}$ for $12 \mathrm{~h}$. The dried samples were allowed to cool to room temperature in a desiccator containing silica gel before measuring sample mass.

\subsection{Statistical Analysis}

All measurements were performed at least in triplicates unless otherwise stated and the results are reported as the mean \pm standard deviation. The Minitab 17 statistical software package (University Park, Pennsylvania, United States) was used for the analysis of 
variance (ANOVA). The significant difference between any two means values was determined using Turkey test. A 95\% ( $\mathrm{p}<0.05)$ confidence level was used in all the cases.

\subsection{RESULTS AND DISCUSSION}

\subsection{Effect Of Inlet-Outlet Air Temperatures On The Physico-Chemical Properties}

\section{Of Co-Microcapsules}

In order to determine the optimal spray drying parameters of producing powdered co-microcapsules, the highest possible survival of encapsulated L. casei, highest oxidative stability (highest OSI) of encapsulated tuna oil and residual moisture content of $5 \%(\mathrm{w} / \mathrm{w})$ were set as three overarching criteria.

\subsubsection{Viability Of Co-Encapsulated Probiotic Bacteria}

The viability of L. casei in these powdered co-microcapsules produced at various inlet/outlet air temperature combinations is presented in Fig. 1. For a given inlet temperature, it was observed that there was a decrease in the viability of L. casei, when the outlet temperature increased from $55^{\circ} \mathrm{C}$ to $75^{\circ} \mathrm{C}$. Various studies have indicated the importance of outlet air temperature associated with the bacterial viability. ${ }^{[30,38]}$ As the droplet and particles are exposed to the outlet temperature in most of their residence time; hence, low outlet air temperatures better protect cells from being over-heated and thus improve the viability. ${ }^{[39]}$ Fig. 1 shows that the survival of L. casei in the co-microcapsules is lower at higher inlet temperatures. Similar findings on the effect of inlet temperatures on bacterial viability have been reported by others. ${ }^{[30,40]}$ Therefore, it can be concluded here that the viability of $L$. casei in these co-microcapsules decreased with increase in 
inlet as well as outlet air temperatures. The highest bacterial survival in these comicrocapsules was observed at inlet/outlet temperature combination of $130 / 55^{\circ} \mathrm{C}(7.3 \mathrm{log}$ cfu/g) followed by at $130 / 65^{\circ} \mathrm{C}$ and $150 / 55^{\circ} \mathrm{C}(7.1 \log \mathrm{cfu} / \mathrm{g})$. The survival of bacteria at these temperature combinations was not significantly different ( $p>0.05$ ) (Fig. 1). The lowest viability of $L$. case $i$ was obtained at inlet/outlet temperature combination of $170 / 75^{\circ} \mathrm{C}(5.5 \log \mathrm{cfu} / \mathrm{g})$. These observations indicate that both inlet and outlet temperatures of spray dryer affect the survival of $L$. casei in WPI-P-O-GA comicrocapsules and that higher inlet and outlet air temperatures are detrimental to the viability of $L$. case $i$ in these co-microcapsules.

\subsubsection{Oxidative Stability Of Co-Encapsulated Omega-3 Oil}

The OSI values of powders produced at different inlet/outlet temperature combinations are presented in Fig. 2. The OSI values of pure tuna oil (control) was measured as 3.1 h. ${ }^{[14]}$ The oxidative stability of co-microcapsules produced at different inlet/outlet temperature combinations was significantly higher than that of untreated tuna oil. As can be observed, there is no statistical difference in OSI values at two lower inlet air temperatures $\left(130^{\circ} \mathrm{C}\right.$ and $\left.150^{\circ} \mathrm{C}\right)$. However, there was a significant decrease in OSI value when higher inlet temperature $\left(170^{\circ} \mathrm{C}\right)$ was used. A large temperature gradient between the droplet/particle and the drying air can occur at high inlet temperature, resulting into faster heat, and moisture transfer rates. Faster outward diffusion of vapour when resisted by microcapsule shell of low moisture diffusivity can create higher number of cracks for unit surface area which can increase the inward diffusion or permeation of the oxygen. It was previously reported that high inlet air temperatures cause excessive 
bubble growth and surface imperfections. ${ }^{[41]}$ This perhaps is the reason for lower OSI values in co-microcapsules dried at higher inlet temperature. Thus, so far it is technically and economically feasible, lower inlet air temperatures should be selected to produce oxidatively stable co-microcapsule powders. The highest and lowest OSI values of $21.2 \mathrm{~h}$ and $15.12 \mathrm{~h}$ were obtained at inlet/outlet combinations of $130 / 65^{\circ} \mathrm{C}$ and $170 / 55^{\circ} \mathrm{C}$, respectively. The OSI values of the co-microcapsules increased with increase in the outlet air temperatures, for each inlet temperature tested except for $130^{\circ} \mathrm{C}$ (Fig. 2).

\subsubsection{Physico-Chemical Characteristics Of Co-Microcapsules}

The residual moisture content, surface oil, total oil, and oil microencapsulation efficiency of spray dried co-microcapsules produced at different inlet/outlet air temperatures are shown in Table 1. As expected, the residual moisture content of powder decreased with increase in the inlet as well as outlet air temperatures in all the cases. This is due to the fact that the relative humidity decreases substantially at higher temperature, and it creates higher vapour gradient between the bulk air and the droplet/particle surface. The effect of higher dryer inlet and outlet temperatures showed similar trend in residual moisture content and bacterial survival. For example, the lowest residual moisture content and the lowest bacterial survival were observed at inlet/outlet temperature combination of $170 / 75^{\circ}$ C. Similarly the highest residual moisture content and the highest bacterial survival was observed at inlet/outlet temperature combination of $130 / 55^{\circ} \mathrm{C}$. Given the residual moisture content of powders obtained from all these temperature combinations was close to $5 \%(\mathrm{w} / \mathrm{w})$, due to highest bacterial survival and highest oxidative stability the inlet/outlet temperature combination of $130 / 65^{\circ} \mathrm{C}$ appeared to be optimal to produce 
WPI-P-O-GA co-microcapsule powder. The thermal efficiency calculated at the inlet/outlet temperature combination of $130 / 65^{\circ} \mathrm{C}$ was found to be $61.90 \%$ (Table 1).

There was no significant difference in surface oil (SO), total oil (TO) and oil microencapsulation efficiency (ME) in the spray dried WPI-P-O-GA co-microcapsules produced at different inlet/outlet temperature combinations (Table 1). This suggests that the complex coacervate matrix rather than the spray drying process determines the amount of surface oil on the WPI-P-O-GA co-microcapsules. This observation agrees with earlier findings that the surface oil in spray dried powders is not affected by outlet ${ }^{[42]}$ and inlet ${ }^{[43]}$ air temperatures. The ME depends on the amount of surface oil of the microcapsules in addition to the degree to which the wall matrix can hold or store the oil within. $\stackrel{[44]}{ }$ Therefore, we can conclude here that surface oil and, hence, the microencapsulation efficiency of these co-microcapsules were mainly affected by the complex coacervate wall matrix rather than the inlet and outlet air temperatures used.

Considering the bacterial viability, OSI and moisture content, it appears that the inlet temperatures $>130^{\circ} \mathrm{C}$ and $<170^{\circ} \mathrm{C}$ and outlet temperatures $>55^{\circ} \mathrm{C}$ and $<75^{\circ} \mathrm{C}$ will produce high quality WPI-P-O-GA co-microcapsules in terms of viability of probiotic bacteria and oxidative stability of omega-3 fatty acids. The co-microcapsules produced at the inlet/outlet air temperatures of $130 / 65^{\circ} \mathrm{C}$ satisfied the three criteria of the highest possible survival of the $L$. casei cells, improved oxidative stability of microencapsulated tuna oil and residual moisture content of $<5 \%(\mathrm{w} / \mathrm{w})$. 


\subsection{Morphology And Surface Characteristics Of WPI-P-O-GA Co-Microcapsules}

\subsubsection{Morphology Of Co-Microcapsules}

Many important properties of microcapsules, such as protection of core materials, powder stability depend on their surface characteristics and surface morphology. ${ }^{[43]}$ The morphology of liquid co-microcapsules observed under phase contrast and SEM microscope (scale bar $=5 \mu \mathrm{m}$ ) is shown in Fig. 3A and Fig. 3B, respectively. The reconstituted spray dried co-microcapsules with additional biological treatment (Section 2.7) was observed under SEM to investigate the morphological change of rod shaped bacteria after drying, which is shown in Fig. 3C. The rod shaped bacteria (represented by white circles) and spherical oil droplets (represented by white arrows) are clearly distinguishable in the matrix (Fig. 3B and 3C). We observed that the morphology of the liquid co-microcapsules changed when observed under SEM (Fig 3B) compared to the one observed under phase contrast (Fig. 3A), probably due the pre-treatment required before SEM imaging (Section 2.7). The sample pretreatment was carried out in order to observe the structural change of bacterial cell before and after spray drying. There was no noticeable alteration in the bacterial cell structure (rod shape) in liquid co-microcapsules (Fig. 3B) and in reconstituted spray dried co-microcapsules (Fig. 3C). This can be attributed to the mild drying condition (inlet/outlet combination of $130 / 65^{\circ} \mathrm{C}$ ), strong evaporative cooling effect, short residence time and resultant lower extent of bacterial denaturation. ${ }^{[45,46]}$ Preservation of structural integrity of bacteria during drying is important for preservation of their viability and vitality. 
The SEM micrographs of spray dried WPI-P-O-GA solid co-microcapsules produced at different inlet/outlet temperature combinations are shown in Fig. 4 (scale bar $=20 \mu \mathrm{m})$. The solid microcapsules obtained are more or less spherical in shape and no bacterial cell was observed on the surface, indicating that L. casei cells were fully encapsulated within the shell matrix. This absence of bacterial cells on the surface of these co-microcapsules is also supported by the surface elemental composition data which will be presented shortly. In addition, there was no observable sign of fissures or cracks on the surface of these WPI-P-O-GA co-microcapsules. This observation further confirms good structural integrity of the co-microcapsule surface which corroborates to the low permeability of oxygen and better microencapsulation efficiency as observed in Table 1. The SEM micrograph of reconstituted WPI-P-O-GA co-microcapsules (Fig. 3C) substantiates the presence of $L$. casei cells and oil droplets inside the co-microcapsules after drying. There was no noticeable difference on the surface morphology in WPI-P-O-GA comicrocapsules produced at different inlet/outlet temperature combinations (Fig. 4).

\subsubsection{Surface Characteristics Of Co-Microcapsules}

XPS analysis was used to quantify the surface (20-100 $\AA$ ) elemental composition of WPI-P-O-GA co-microcapsules. The C1s spectra of these co-microcapsules at various inlet/outlet temperature combinations are shown in Fig. 5. The corresponding surface elemental composition in terms of carbon $(C)$, oxygen $(O)$, nitrogen $(N)$ of these co-microcapsules are presented in Table 2. The concentration of carbon atoms bonded differently or bonded with different elements was determined by curve-fitting the high resolution $\mathrm{C} 1 \mathrm{~s}$ spectra. The curve fitting protocol was based on five components with the 
following notations: $\mathrm{C} 1+\mathrm{C} 2(\mathrm{C}-\mathrm{C}, \mathrm{C}-\mathrm{H}), \mathrm{C} 3(\mathrm{C}-\mathrm{O}, \mathrm{C}-\mathrm{N}), \mathrm{C} 4(\mathrm{C}=\mathrm{O}, \mathrm{O}-\mathrm{C}-\mathrm{O}, \mathrm{N}-\mathrm{C}=\mathrm{O}), \mathrm{C} 5$ $(\mathrm{O}-\mathrm{C}=\mathrm{O})$. As can be seen from Fig. 5, the $\mathrm{C} 1 \mathrm{~s}$ spectra of all the co-microcapsules are overlapping with each other. This means that the spray dried WPI-P-O-GA comicrocapsules produced at different inlet/outlet temperature combinations had identical surface elemental composition and that the drying parameters made no difference on the surface composition. This observation also corroborates with the surface oil data (Table 1) which showed that there was no significant difference $(p>0.05)$ in the surface oil content in WPI-P-O-GA co-microcapsules produced at different inlet/outlet temperature combinations. Furthermore, there was no significant difference in oxygen and nitrogen content on the surface of co-microcapsules produced at different inlet/outlet air temperature combinations (Table 2). However, the least oxygen content (0.196) was found on the surface of co-microcapsules produced at inlet/outlet temperature combination of $130 / 65^{\circ} \mathrm{C}$. This observation also corroborates with the oxidative stability index data (Fig. 2) which showed that co-microcapsules produced at inlet/outlet temperature combination of $130 / 65^{\circ} \mathrm{C}$ exhibited highest oxidative stability (21.2 h) than those produced at other inlet/outlet temperature combinations.

\subsection{CONCLUSIONS}

The probiotic bacteria $L$. casei and omega-3 rich tuna oil were co-encapsulated using WPI-GA complex coacervate as shell material and subsequently converted into powder using spray drying. Nine sets of spray dryer inlet/outlet temperature combinations were used to determine the effects of these temperature combinations on properties such as bacterial survival, stability of oil against oxidation, moisture content, surface oil, total oil, 
oil microencapsulation efficiency as well as surface morphology and surface elemental composition of these co-microcapsules. High inlet and outlet air temperatures decreased the survival of $L$. casei. High inlet air temperature also decreased oxidative stability of microencapsulated tuna oil. Surface oil content and hence the oil microencapsulation efficiency of WPI-P-O-GA co-microcapsules was not affected by the inlet and outlet temperatures. The shape and the morphology of $L$. casei cells were not affected by the chosen spray drying temperatures. The surface morphology of co-microcapsules produced at different inlet/outlet temperature combinations was not significantly different. The inlet air temperatures from $130^{\circ} \mathrm{C}$ to $170^{\circ} \mathrm{C}$ and outlet temperatures between $55^{\circ} \mathrm{C}$ and $75^{\circ} \mathrm{C}$ different did not alter the surface elemental composition of these spray dried co-microcapsules. This study identified that the inlet/outlet temperature combination of $130 / 65^{\circ} \mathrm{C}$ produced WPI-P-O-GA co microcapsules with highest bacterial survival and highest oxidative stability under moisture content less than 5\%. These findings of this study will benefit many potential applications in functional food, nutraceutical and pharmaceutical industries.

\section{ACKNOWLEDGEMENTS}

The first author acknowledges the Australian Postgraduate Award (APA) provided to her by the Australian Federal Government. The authors wish to thank Bruce Armstrong, Stafford McKnight and Dr. Bo Wang for technical help during experiments.

\section{REFERENCES}


[1] Adhikari, B.; Howes, T.; Shrestha, A.; Bhandari, B. Development of stickiness of whey protein isolate and lactose droplets during convective drying. Chemical Engineering and Processing: Process Intensification 2007, 46 (5), 420-428.

[2] Annunziata, A.; Vecchio, R. Consumer perception of functional foods: A conjoint analysis with probiotics. Food Quality and Preference 2013, 28 (1), 348-355.

[3] Anwar, S.H.; Kunz, B. The influence of drying methods on the stabilization of fish oil microcapsules: Comparison of spray granulation, spray drying, and freeze drying. Journal of Food Engineering 2011, 105 (2), 367-378.

[4] Arpagaus, C.; Schwartzbach, H. Scale-up from the Büchi Mini Spray Dryer B-290 to the Niro Mobile Minor. Buchi Labortechnik AG 2012.

[5] Atalar, I.; Dervisoglu, M. Optimization of spray drying process parameters for kefir powder using response surface methodology. LWT - Food Science and Technology 2015, 60 (2, Part 1), 751-757.

[6] Champagne, C.P.; Fustier, P. Microencapsulation for the improved delivery of bioactive compounds into foods. Current opinion in biotechnology 2007, 18 (2), 184-190.

[7] Chávez, B.; Ledeboer, A. Drying of probiotics: optimization of formulation and process to enhance storage survival. Drying Technology 2007, 25 (7-8), 1193-1201.

[8] Coman, M.M.; Cecchini, C.; Verdenelli, M.C.; Silvi, S.; Orpianesi, C.; Cresci, A. Functional foods as carriers for $\mathrm{SYNBIO} \circledast$, a probiotic bacteria combination. International journal of food microbiology 2012, 157 (3), 346-352.

[9] Comunian, T.A.; Thomazini, M.; Alves, A.J.G.; de Matos Junior, Fernando Eustáquio; de Carvalho Balieiro, Júlio C; Favaro-Trindade, C.S. Microencapsulation of 
ascorbic acid by complex coacervation: Protection and controlled release. Food Research International 2013, 52 (1), 373-379.

[10] Danviriyakul, S.; McClements, D.; Decker, E.; Nawar, W.; Chinachoti, P. Physical Stability of Spray- Dried Milk Fat Emulsion as Affected by Emulsifiers and Processing Conditions. Journal of Food Science 2002, 67 (6), 2183-2189.

[11] Desai, K.G.H.; Jin Park, H. Recent developments in microencapsulation of food ingredients. Drying Technology 2005, 23 (7), 1361-1394.

[12] Dinnetz, J.M.; Furtney, S.R.; Pendergraft, J.S.; Davis, E.G.; Epp, T.S.; Minton, J.E. Omega-3 Fatty Acid Supplementation Reduces Basal TNFa but Not Toll-Like $\underline{\text { Receptor-Stimulated TNF } \alpha \text { in Full-Sized and Miniature Mares. Journal of Equine }}$ Veterinary Science 2013, 33 (7), 523-529.

[13] Earle, M.D. Innovation in the food industry. Trends in Food Science \& Technology 1997, 8 (5), 166-175.

[14] Eratte, D.; McKnight, S.; Gengenbach, T.R.; Dowling, K.; Barrow, C.J.; Adhikari, B.P. Co-encapsulation and characterisation of omega-3 fatty acids and probiotic bacteria in whey protein isolate-gum Arabic complex coacervates. Journal of Functional Foods 2015.

[15] Eratte, D.; Wang, B.; Dowling, K.; Barrow, C.J.; Adhikari, B.P. Complex coacervation with whey protein isolate and gum arabic for the microencapsulation of omega-3 rich tuna oil. Food Funct. 2014, 5 (11), 2743-2750.

[16] Fu, N.; Woo, M.W.; Selomulya, C.; Chen, X.D. Inactivation of Lactococcus lactis ssp. cremoris cells in a droplet during convective drying. Biochemical engineering journal 2013, 79, 46-56. 
[17] Ghandi, A.; Powell, I.B.; Chen, X.D.; Adhikari, B. The survival of lactococcus lactis in a convective-air-drying environment: The role of protectant solids, oxygen injury, and mechanism of protection. Drying Technology 2013, 31 (13-14), 1661-1674.

[18] Ghandi, A.; Powell, I.B.; Chen, X.D.; Adhikari, B. The effect of dryer inlet and outlet air temperatures and protectant solids on the survival of Lactococcus lactis during spray drying. Drying Technology 2012, 30 (14), 1649-1657.

[19] Gomes, A.M.P.; Malcata, F.X. Bifidobacterium spp. and Lactobacillus acidophilus: biological, biochemical, technological and therapeutical properties relevant for use as probiotics. Trends in Food Science \& Technology 1999, 10 (4-5), 139-157.

[20] Gouin, S. Microencapsulation: industrial appraisal of existing technologies and trends. Trends in Food Science \& Technology 2004, 15 (7), 330-347.

[21] Hogan, S.A.; McNamee, B.F.; O'Riordan, E.D.; O'Sullivan, M. Emulsification and microencapsulation properties of sodium caseinate/carbohydrate blends. International Dairy Journal 2001, 11 (3), 137-144.

[22] Hui, Y.H. Food Drying Science and Technology: Microbiology, Chemistry, Applications: DEStech Publications, Inc, 2008.

[23] I Ré, M. Microencapsulation by spray drying. Drying Technology 1998, 16 (6), 1195-1236.

[24] Jafari, S.M.; Assadpoor, E.; He, Y.; Bhandari, B. Encapsulation efficiency of food flavours and oils during spray drying. Drying Technology 2008, 26 (7), 816-835.

[25] Joint FAO/WHO Expert Committee on Food Additives. Meeting; World Health Organization Safety Evaluation of Certain Mycotoxins in Food: Food \& Agriculture Org., 2001. 
[26] Jun-xia, X.; Hai-yan, Y.; Jian, Y. Microencapsulation of sweet orange oil by complex coacervation with soybean protein isolate/gum Arabic. Food Chemistry 2011, $125(4), 1267-1272$.

[27] Keshani, S.; Daud, W.R.W.; Nourouzi, M.M.; Namvar, F.; Ghasemi, M. Spray drying: An overview on wall deposition, process and modeling. Journal of Food Engineering 2015, $146(0), 152-162$. [28] Kim, S.; Cho, S.Y.; Kim, S.H.; Song, O.; Shin, I.; Cha, D.S.; Park, H.J. Effect of microencapsulation on viability and other characteristics in Lactobacillus acidophilus ATCC 43121. LWT - Food Science and Technology 2008, 41 (3), 493-500.

[29] Klinkesorn, U.; Sophanodora, P.; Chinachoti, P.; Decker, E.A.; McClements, D.J. Characterization of spray-dried tuna oil emulsified in two-layered interfacial $\underline{\text { membranes prepared using electrostatic layer-by-layer deposition. Food Research }}$ International 2006, 39 (4), 449-457.

[30] Knorr, D. Technology aspects related to microorganisms in functional foods. Trends in Food Science \& Technology 1998, 9 (8), 295-306.

[31] Koc, B.; Yilmazer, M.S.; Balkır, P.; Ertekin, F.K. Spray drying of yogurt: Optimization of process conditions for improving viability and other quality attributes. Drying Technology 2010, 28 (4), 495-507.

[32] Liu, S.; Low, N.; Nickerson, M.T. Entrapment of flaxseed oil within gelatin-gum arabic capsules. Journal of the American Oil Chemists' Society 2010, 87 (7), 809-815. [33] Mathäus, B.W. Determination of the oxidative stability of vegetable oils by $\underline{\text { Rancimat and conductivity and chemiluminescence measurements. Journal of the }}$ American Oil Chemists' Society 1996, 73 (8), 1039-1043. 
[34] Mazza, M.G.; Brandão, L.E.; Wildhagen, G.S. Characterization of the residence time distribution in spray dryers. Drying Technology 2003, 21 (3), 525-538.

[35] Nazzaro, F.; Orlando, P.; Fratianni, F.; Coppola, R. Microencapsulation in food science and biotechnology. Current opinion in biotechnology 2012, 23 (2), 182-186. [36] Olive Li, Y.; Dueik González, V.P.; Diosady, L.L. Chapter 38 - Microencapsulation of Vitamins, Minerals, and Nutraceuticals for Food Applications. In Microencapsulation in the Food Industry; Gaonkar, A.G.; Vasisht, N.; Khare, A.R.; Sobel, R., Eds.: Academic Press; San Diego; 2014; 501-522.

[37] Oliveira, A.; Moretti, T.; Boschini, C.; Baliero, J.; Freitas, O.; Favaro-Trindade, C. Stability of microencapsulated B. lactis (BI 01) and L. acidophilus (LAC 4) by complex coacervation followed by spray drying. Journal of microencapsulation 2007, 24 (7), 685-693.

[38] Parvez, S.; Malik, K.A.; Ah Kang, S.; Kim, H.-. Probiotics and their fermented food products are beneficial for health. Journal of applied microbiology 2006, 100 (6), 11711185.

[39] Perdana, J.; Bereschenko, L.; Fox, M.B.; Kuperus, J.H.; Kleerebezem, M.; Boom, R.M.; Schutyser, M.A.I. Dehydration and thermal inactivation of Lactobacillus plantarum WCFS1: Comparing single droplet drying to spray and freeze drying. Food Research International 2013, 54 (2), 1351-1359.

[40] Price Judge, M.; Francisca Diallo, A.; Tatano Beck, C. Chapter 11 - The Effects of Omega-3 Polyunsaturated Fatty Acids on Maternal and Child Mental Health. In Omega-3 Fatty Acids in Brain and Neurological Health; Meester, R.R.W.D., Ed.: Academic Press; Boston; 2014; 121-129. 
[41] Serfaty, C.A.; de Velasco, P.C. Chapter 10 - Low Omega-3 Fatty Acids Diet and the Impact on the Development of Visual Connections and Critical Periods of Plasticity. In Omega-3 Fatty Acids in Brain and Neurological Health; Meester, R.R.W.D., Ed.: Academic Press; Boston; 2014; 109-120.

[42] Sobel, R.; Versic, R.; Gaonkar, A.G. Chapter 1 - Introduction to Microencapsulation and Controlled Delivery in Foods. In Microencapsulation in the Food Industry; Gaonkar, A.G.; Vasisht, N.; Khare, A.R.; Sobel, R., Eds.: Academic Press; San Diego; 2014; 3-12. [43] Sousa, G.T.; Lira, F.S.; Rosa, J.C.; de Oliveira, E.P.; Oyama, L.M.; Santos, R.V.; Pimentel, G.D. Dietary whey protein lessens several risk factors for metabolic diseases: a review. Lipids Health Dis 2012, 11 (1), 67.

[44] Tripathi, M.K.; Giri, S.K. Probiotic functional foods: Survival of probiotics during processing and storage. Journal of Functional Foods 2014, 9 (0), 225-241.

[45] Wang, B.; Adhikari, B.; Barrow, C.J. Optimisation of the microencapsulation of tuna oil in gelatin-sodium hexametaphosphate using complex coacervation. Food Chemistry 2014, 158, 358-365.

[46] Williams, P.; Phillips, G. Gum arabic. Handbook of hydrocolloids 2009, 252-273. 
Table 1: Physico-chemical properties of spray dried WPI-P-O-GA co-microcapsules and thermal efficiency of spray drying process at different inlet/outlet air temperatures. $\mathrm{SO}=$ Surface oil, $\mathrm{TO}=$ Total oil, $\mathrm{ME}=$ Oil microencapsulation efficiency, $\eta_{\text {\hemal }}=$ Thermal efficiency of spray drying process.

\begin{tabular}{|l|l|l|l|l|l|}
\hline $\begin{array}{l}\text { Inlet/outlet } \\
\text { temperature } \\
\left({ }^{\circ} \mathbf{C}\right)\end{array}$ & Residual moisture & & & & \\
\hline $130 / 55$ & content (\%) & SO (\%) & TO (\%) & Oil ME (\%) & $\mathbf{\eta}_{\text {thermal }}(\%)$ \\
\hline $130 / 65$ & $5.03 \pm 0.07^{\mathrm{a}}$ & $2.85 \pm 0.28^{\mathrm{a}}$ & $48.25 \pm 1.11^{\mathrm{a}}$ & $94.08 \pm 0.60^{\mathrm{a}}$ & 71.43 \\
\hline $130 / 75$ & $4.93 \pm 0.05^{\text {ab }}$ & $2.68 \pm 0.70^{\mathrm{a}}$ & $47.57 \pm 2.09^{\mathrm{a}}$ & $94.32 \pm 1.68^{\mathrm{a}}$ & 61.90 \\
\hline $150 / 55$ & $4.72 \pm 0.05^{\text {abc }}$ & $2.80 \pm 0.73^{\mathrm{a}}$ & $48.74 \pm 1.40^{\mathrm{a}}$ & $94.24 \pm 1.59^{\mathrm{a}}$ & 52.38 \\
\hline $150 / 65$ & $4.66 \pm 0.33^{\text {abcd }}$ & $2.83 \pm 0.87^{\mathrm{a}}$ & $48.86 \pm 0.85^{\mathrm{a}}$ & $94.23 \pm 1.69^{\mathrm{a}}$ & 76.00 \\
\hline $150 / 75$ & $4.27 \pm 0.28^{\text {bcde }}$ & $2.96 \pm 0.43^{\mathrm{a}}$ & $48.63 \pm 1.50^{\mathrm{a}}$ & $93.91 \pm 0.81^{\mathrm{a}}$ & 68.00 \\
\hline $170 / 55$ & $3.07 \pm 0.51^{\text {cdef }}$ & $2.61 \pm 1.05^{\mathrm{a}}$ & $47.62 \pm 1.50^{\mathrm{a}}$ & $94.49 \pm 2.35^{\mathrm{a}}$ & 60.00 \\
\hline $170 / 65$ & $3.69 \pm 0.20^{\text {def }}$ & $3.14 \pm 1.27^{\mathrm{a}}$ & $47.81 \pm 1.27^{\mathrm{a}}$ & $93.39 \pm 2.84^{\mathrm{a}}$ & 79.31 \\
\hline $170 / 75$ & $3.32 \pm 0.20^{\mathrm{f}}$ & $3.07 \pm 1.07^{\mathrm{a}}$ & $48.66 \pm 0.57^{\mathrm{a}}$ & $93.69 \pm 2.18^{\mathrm{a}}$ & 72.41 \\
\hline
\end{tabular}


Table 2: Surface elemental compositions [Carbon (C), Oxygen (O), and Nitrogen (N)] of spray-dried WPI-P-O-GA co-microcapsules produced at varying inlet/outlet air temperatures. Presented are the mean ( \pm std. dev.) of two measurements (atomic concentrations relative to total concentration of carbon). See text for details.

\begin{tabular}{|l|l|l|l|l|l|l|}
\hline Inlet/outlet & & & & & \\
temperature & & & & & & \\
$\left({ }^{\circ} \mathbf{C}\right)$ & $\mathbf{C 1}+\mathbf{C 2}$ & $\mathbf{C 3}$ & $\mathbf{C 4}$ & $\mathbf{C 5}$ & $\mathbf{O}$ & $\mathbf{N}$ \\
\hline $130 / 55$ & $0.716 \pm .002$ & $0.156 \pm .000$ & $0.064 \pm .000$ & $0.064 \pm .002$ & $0.215 \pm .003$ & $0.072 \pm .001$ \\
\hline $130 / 65$ & $0.736 \pm .007$ & $0.145 \pm .002$ & $0.058 \pm .002$ & $0.061 \pm .003$ & $0.196 \pm .010$ & $0.062 \pm .003$ \\
\hline $130 / 75$ & $0.714 \pm .004$ & $0.159 \pm .005$ & $0.067 \pm .000$ & $0.060 \pm .001$ & $0.209 \pm .003$ & $0.073 \pm .001$ \\
\hline $150 / 55$ & $0.733 \pm .004$ & $0.145 \pm .002$ & $0.058 \pm .002$ & $0.064 \pm .000$ & $0.202 \pm .006$ & $0.061 \pm .003$ \\
\hline $150 / 65$ & $0.720 \pm .004$ & $0.154 \pm .003$ & $0.067 \pm .000$ & $0.060 \pm .001$ & $0.209 \pm .003$ & $0.071 \pm .002$ \\
\hline $150 / 75$ & $0.715 \pm .003$ & $0.156 \pm .004$ & $0.068 \pm .003$ & $0.061 \pm .002$ & $0.214 \pm .004$ & $0.072 \pm .001$ \\
\hline $170 / 55$ & $0.726 \pm .000$ & $0.148 \pm .003$ & $0.064 \pm .005$ & $0.062 \pm .001$ & $0.208 \pm .003$ & $0.065 \pm .000$ \\
\hline $170 / 65$ & $0.719 \pm .001$ & $0.149 \pm .001$ & $0.070 \pm .002$ & $0.062 \pm .000$ & $0.220 \pm .002$ & $0.071 \pm .001$ \\
\hline $170 / 75$ & $0.716 \pm .002$ & $0.152 \pm .001$ & $0.071 \pm .001$ & $0.061 \pm .001$ & $0.218 \pm .006$ & $0.074 \pm .005$ \\
\hline
\end{tabular}


Fig. 1: Survival of $L$. casei in spray dried WPI-P-O-GA co-microcapsules at different inlet/outlet air temperature combinations. The labelled data corresponds to the viability in $\log (\mathrm{cfu} / \mathrm{g})$. The bars with different letter in supercript indicate significant difference $(\mathrm{p}<$ $0.05)$.

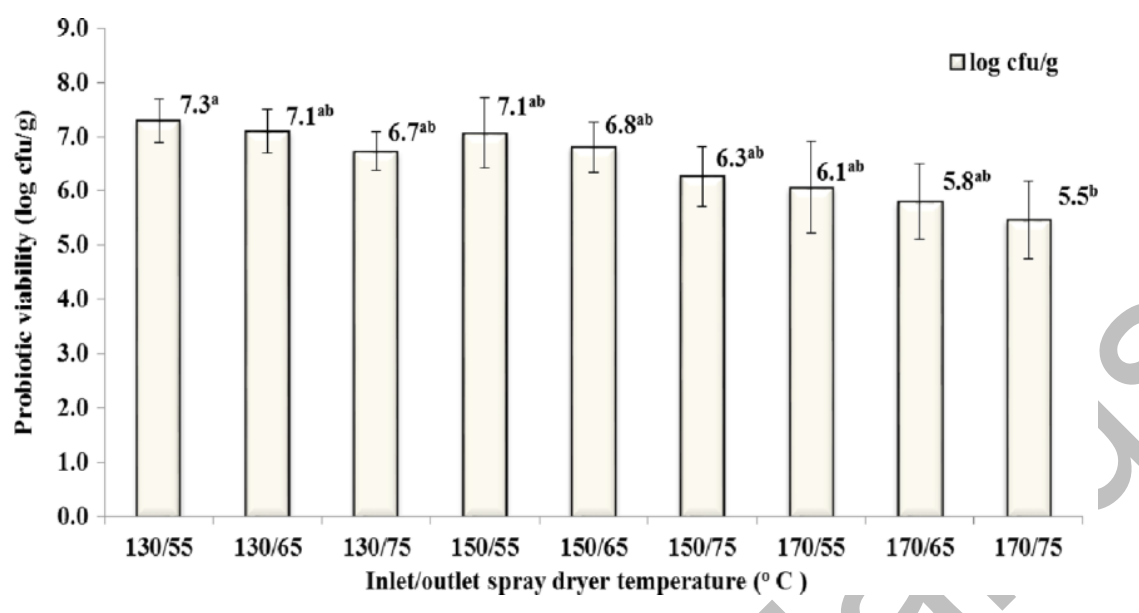


Fig. 2: Oxidative stability index (OSI) of encapsulated tuna oil in spray dried WPI-P-OGA co-microcapsules at different inlet/outlet air temperature combinations. The labelled data indicates the oxidative stability index (OSI). Different lower case letters in superscript indicate significant difference $(\mathrm{p}<0.05)$.

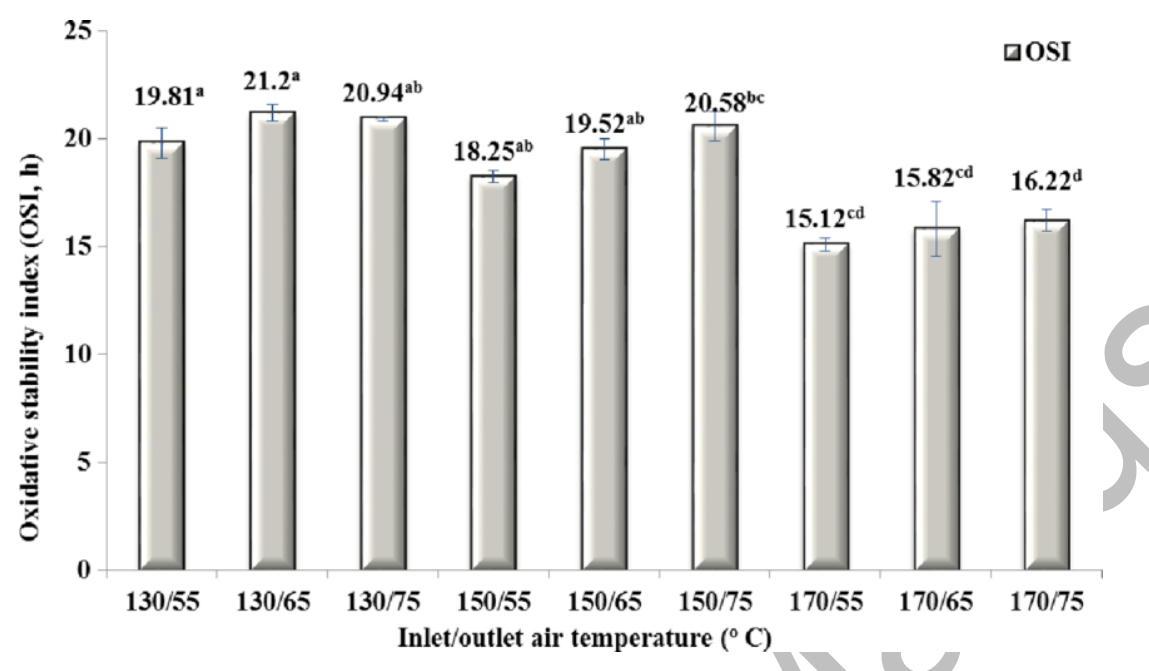


Fig. 3: Morphology of WPI-P-O-GA co-microcapsules: (A) Liquid co-microcapsules observed under phase contrast microscope; (B) Liquid co-microcapsules observed under SEM; (C) Reconstituted spray dried co-microcapsules obtained under SEM, scale bar =5 $\mu \mathrm{m}$.
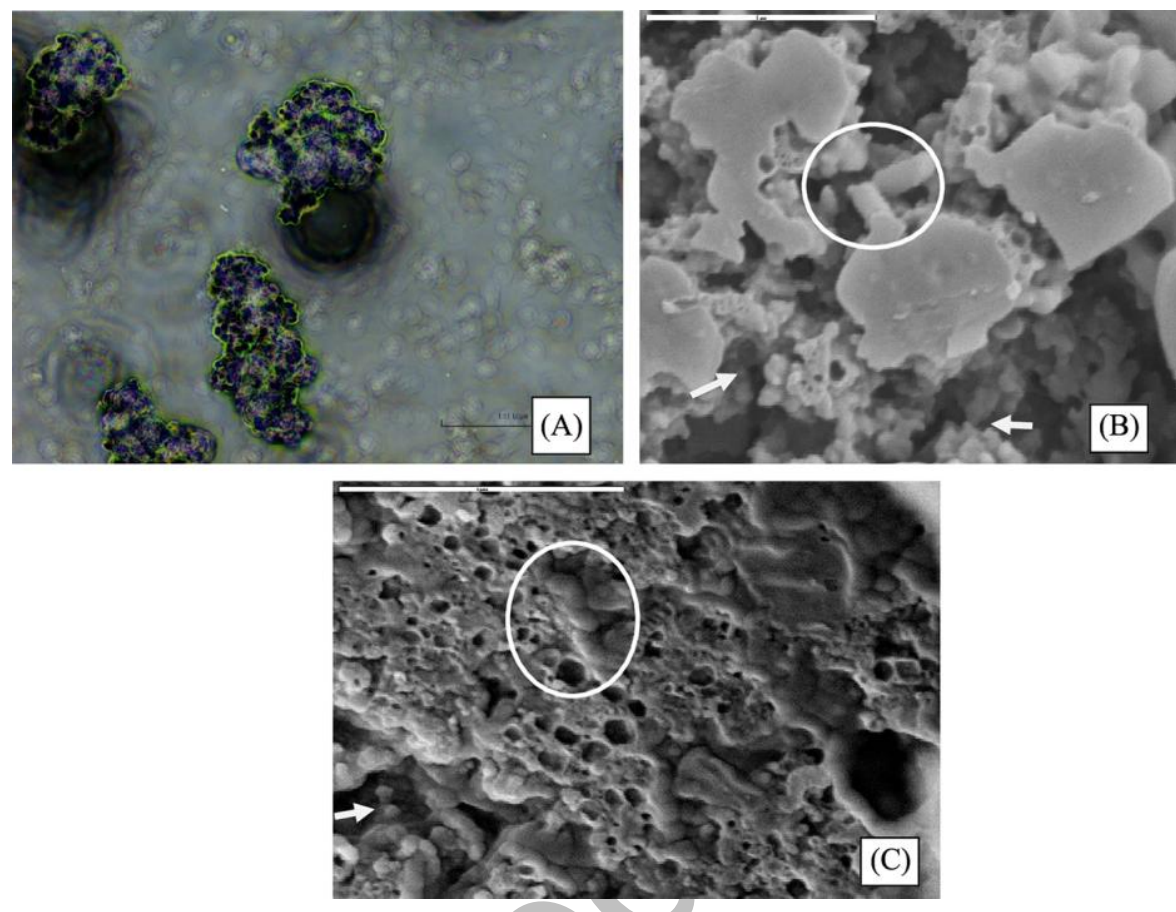
Fig. 4: SEM micrographs of WPI-P-O-GA co-microcapsules produced at different inlet/outlet temperature combinations $\left({ }^{\circ} \mathrm{C}\right.$ ): (A) 130/55; (B) 130/65; (C) 130/75; (D) 150/55; (E) 150/65; (F) 150/75; (G) 170/55; (H) 170/65; (I) 170/75; scale bar $=20 \mu \mathrm{m}$.
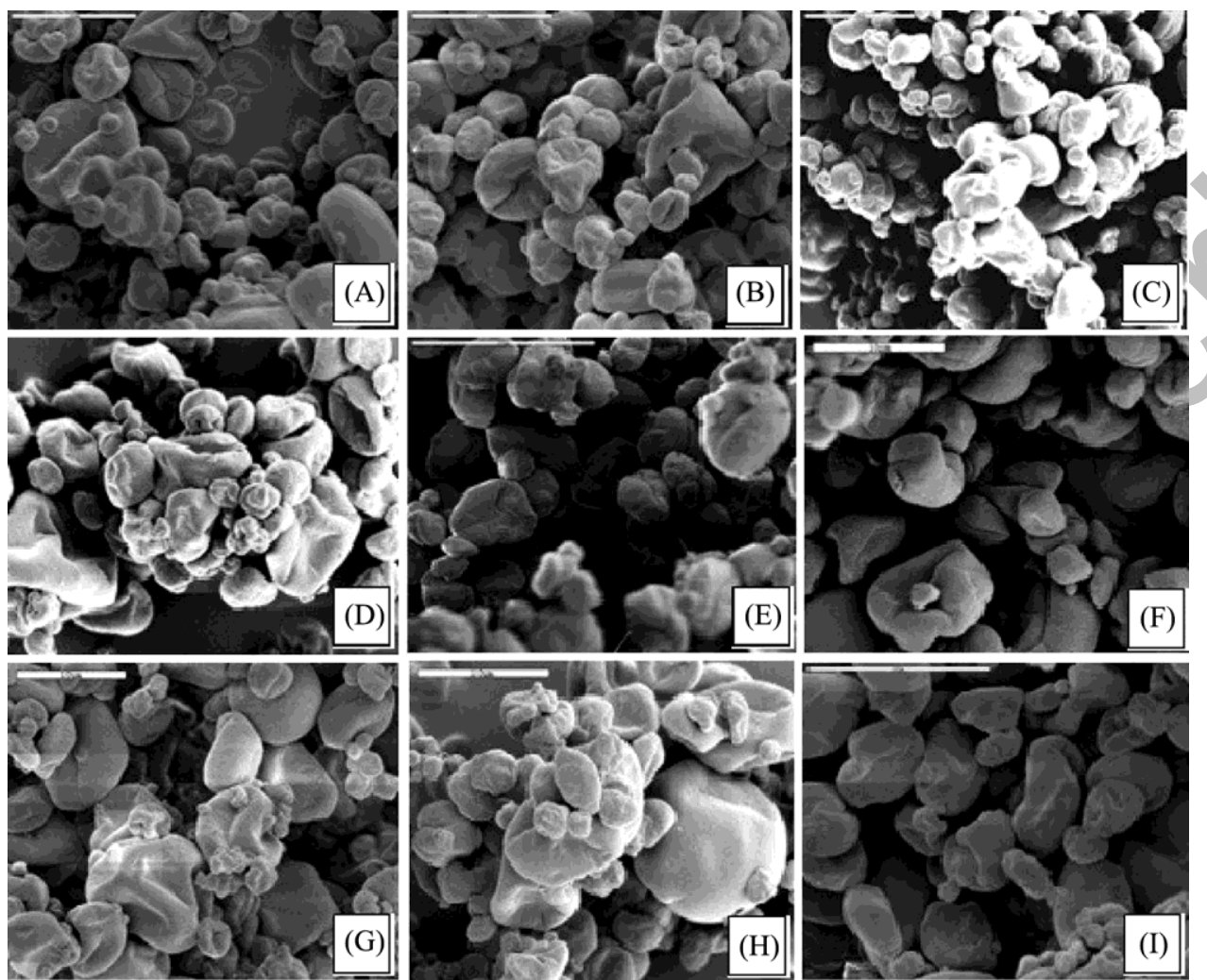
Fig. 5: C1s spectra of spray dried WPI-P-O-GA co-microcapsules produced at different inlet/outlet air temperature combinations $\left({ }^{\circ} \mathrm{C}\right.$ ): (A) 130/55; (B) 130/65; (C) 130/75; (D) 150/55; (E) 150/65; (F) 150/75; (G) 170/55; (H) 170/65; (I) 170/75.

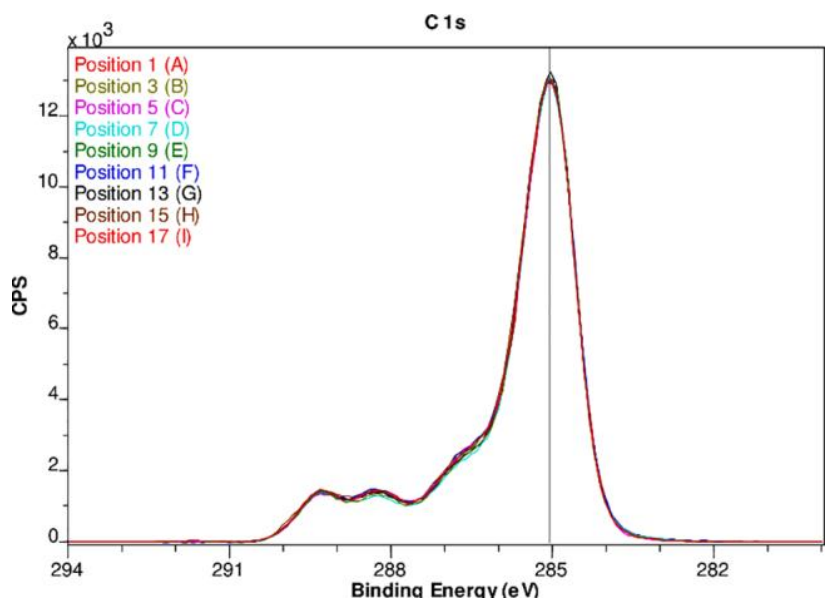

